Života Radosavljević, $\mathrm{PhD}^{1}$

Faculty of Business Studies and Law, Union University „Nikola Tesla“, Belgrade

Milan Radosavljević, $\mathrm{PhD}^{2}$

Aleksandar Anđelković ${ }^{3}$

Faculty of Strategic and Operational Managment,

Union University „Nikola Tesla“, Belgrade
ORIGINAL SCIENTIFIC ARTICLE

Received: January 15, 2015

Accepted: February 23, 2015

\title{
THE NECESSITY OF ELIMINATING CLASSICAL CONCEPTS AND INTRODUCTION OF NEW CONCEPTS INTO STRATEGIC MANAGEMENT AND BUSINESS
}

\begin{abstract}
The fact is that even today in the management of developed countries they apply the concept of strategy defined in the eighties by Michelle Porter. This concept is based on both classic and mechanistic basis, i.e. determinism and the organization chart that was effective in terms of small changes and a high degree of certainty in management decisions. Therefore, the fact that Porter's concept of strategy had not changed for more than three decades and is as such still applied and analyzed at high business schools in the West is reason enough for this concept to deteriorate leading to the final outcome - death .

With evident turbulent and radical changes, Porter's concept of strategy is inefficient and it must be replaced with new approaches and concepts based on biologistical-medical grounds, which are natural, and hence more objective to formulate quality strategy and strategic decisions. It turns out that it is necessary to redefine the postulates of classic strategies and set a new basis, i.e. new strategy for the development and implementation of strategies, and the introduction of new, primarily adaptive, flexible, and strategies shaping the environment, which are relatively unknown today, or neglected.

This paper aims to highlight the necessity of abandoning the classic strategy in strategic management and the necessity of introducing those concepts that take into account volatility and the high level of uncertainty that exists today and will in the future be even greater.
\end{abstract}

Keywords: Classical strategies, new concepts of strategy, strategy problems

JEL classification: M2, M20, M21

\section{НУЖНОСТ ЕЛИМИНИСАЊА КЛАСИЧНИХ И УВОЪЕЊЕ НОВИХ КОНЦЕПАТА У СТРАТЕШКОМ МЕНАЏМЕНТУ И БИЗНИСУ}

\begin{abstract}
Апстракт
Чињенииа је да се и данас у менаименту развијених земаља примењује кониепт стратегије коју је поставио осамдесетих година прошлог века
\end{abstract}

\footnotetext{
${ }^{1}$ zivota.radosavljevic@fpsp.edu.rs

2 milan.radosavljevic@fpsp.edu.rs

3 aca.andjelkovic@fpsp.edu.rs
} 
Мишел Портер. Овај концепт се заснива на класичним и механистичким основама, односно на детерминизму и шематизму и био је ефикасан у условима малих промена и високог степена извесности управљачких одлука. Самим тим, ито се Портеров концепт стратегије није мењао више од три деценије и што се као такав данас применује и изучава на високим пословним школама (хигхт бусинесс сихоол) Запада, је довољан разлог за његово пропадање које доводи до коначног исхода, а то је смрт.

У условима турбулентних и радикалних промена, Портеров концепт стратегије је неефикасан и нужно је исти заменити са новим приступима, односно концепттима који се заснивају на биологистичко-медицинским основама, који су природни, а тиме и објективнији за формулисање квалитетних стратегија и стратегијских одлука. Показује се да је нужно редефинисати постулате класичне стратегије и поставити нове основе, односно нову стратегију за израду и имплементацију стратегије, као и увођење нових, а пре свега адаптивних, флексибилних и стратегија обликовања окружења, које су данас релативно непознате, или запостављене.

Рад има за циљ да укаже на нужност напуштања класичних стратегија y стратегијском менацменту и неопходност увођења оних конщепата који уважавају турбулентност и висок ниво неизвесности који данас постоји и који ће у будућности бити још и већи.

Кључне речи: Класична стратегија, нови концепти стратегије, проблеми cmpaтегије.

\section{Is strategy science?}

Studies show that the strategy is several thousand years old. Strategy is mentioned both in war doctrines and in conducts of wars. In each new time dimension man tried to increase effectiveness in conflicts between different tribes, using effective tools and weapons, different concepts of warfare, etc. As a rule, every new weapon had changed the concept of waging a war, thus increasing the success in conquering territory, or enslave other tribes or nations. When slaves were replaced with professional armies this gave military strategy a whole new quality.

No matter when strategy is created and where it is being implemented, strategy is always a set of integrated decisions, actions and plans, whose task is to achieve the defined objectives of the organization or society. It is the result of the analysis and evaluation of organizational performance and their compliance with the opportunities and threats in the environment. Therefore, strategy itself is not a goal, nor is strategy used to define objectives, as it is often stated in the literature, but it is an instrument for achieving the defined objectives.

Classic theorists and general management theory in the sixties found that strategic management is indeed a scientific discipline of its own, and that claim was further developed in the seventies and eighties. View that strategy is interdisciplinary science prevails in strategic management today.

Further analysis shows that we might rightfully pose the following qustion: is strategy science at all?

Experience has shown that whenever a certain phenomenon was widely spoken about without adequate arguments there invariably existed a problem in the scientific 
explanation of these phenomena. Therefore, conclusions without scientific verification can be misleading, i.e. existing concepts may turn into stereotypes and laws that are not being addressed.

Too many citations and quotation by a famous Chinese strategist Sun Tzu show that many authors tend to mechanically transfer certain laws of war strategy into business sphere, and beyond. For example, D. Cawood talks about military strategy in business emphasizing that principles of military strategy can be used in the conduct of market struggle, especially in a market environment where modern economic activity may be compared to a battlefield where every day a large number of companies disappear, leaving behind greater havoc than in a conventional war. (Millson \& Wilemon p.657) We must keep in mind that military strategy itself has changed rendering its implementation impossible, not only because we face a fundamentally changed environment, but also because war strategy is aimed at the 'waging warfare with modern weapons, without participation of the life force, at a distance, where many elements of the classic military strategy do not work, or are marginalized.

\subsection{Arguments that support the claim that strategy is science}

The fact is that modern management is designed on classic basis which was designed by Western theorists of organization and management. Its features include: determinism, schematism and hierarchy, i.e. relations of dominance and subordination. In this concept, the dominant role was played by material resources, while human potential was neglected and considered to be a mere 'machine tag.' In the second half of the twentieth century classic management provided satisfactory results and was the most perfect mode of management of organizations. All things created on earthin the past five decades are more or less results of this and similar types of management. It is still present in traditional organizations and traditional industries.

Porter's concept of strategy originated in the mid eighties in the framework of classical management and had its characteristic features. From this distance, this concept is not old, but technical, technological, organizational, economic and socio-political environment and changes had made it obsolete, thus questionning its applicability in the form set by Porter. It turns out that now there are no gradual and predictable changes, no industrial organization, the number of workers classified as 'blue coats' is drastically reduced with tendency to completely disappear because there will be no jobs for them to perform. Today we face the knowledge society dominated by intellectual organizations, or 'white coats' and 'golden collars'. Instead of material factors, knowledge has become the most important potential. In a word, there have been radical and fundamenalne changes that have significantly changed the design of the organization and management.

The claim that strategy is science is based on the indisputable fact that it is taught, as well as other sciences, in reputable high business schools around the world, for more than five decades now. A significant number of colleges, institutes, faculties in the field of business and management had been created as early as the sixties and their curricula also includes strategy and strategic management in various fields. Further, a significant number of scientific papers have been published in this field in recognized international journals, and there are scientific positions in this field, too. Clausewitz, one of the worldrenowned experts on strategy, strategy is 'science because it aims, just like all other sciences, to learn things, i.e. to process knowledge necessary to conduct the fight.' However, he further believes that strategy must be followed by skill, i.e. it is not enough to know the principles of strategy, it is necessary to have the skills to implement it.

From the above it can be concluded that strategy, like other sciences, has its own subject, 
the methodology and scientific apparatus for drawing conclusions and principles that should not be questioned. Its principles are derived from warfare, or from experiments in different organizations. For example, through the chronographer Taylor used to measure performance, and on that basis he would set norms for certain jobs and tasks. Based on this, he would plan certain individual stages of the production process. The last and most important experiment that was conducted in the field of management and motivation is the so-called Hawthorn's experiment conducted at the Western Electric Company in Chicago in the twenties and thirties by E. Mayo and associates. This experiment was related to the study of working conditions (microclimate, noise, lighting, and other factors) on the productivity of labor, and whether and what extent supervision contributes to work performance. This experiment was a prelude to the emergence of neoclassical theory of organization and management, which radically changed the organization. On the basis of these studies the so-called Hawtorne's effect was formulated, which boiles down to the following: isolated individuals can increase their impact more through increased attention and inter-personal respect than through the introduction of tests and controls that had been dominant up to then (Barton, \& Martin, p.50). Later concepts of management, such as the X, Y, Z, theories of motivation and organizational building, are but modalities of the Hawthorne experiment. Business colleges around the world teach the elements of strategies, such as operational art, and tactics, working with people, morality, etc.

Bearing this in mind, strategy was further diversified by different criteria and was often analyzed through various sciences such as military science, industry, agriculture, tourism, services, etc. Strategy was also treated from the national level, level of organizational systems, and from the standpoint of individual functional areas, therefore we have national strategy, corporate, functional strategy such as production, finance, marketing or development strategy, quality strategy, etc. That is how strategy has become not only science, but a multidisciplinary science. Strategy has been using the achievements and findings of an overall strategy, but each branch strategy, corporate or functional strategy treated and explored certain specifics.

Apparently, strategy is applied activity because it points out the ways how to achieve goals. Large multinational companies have strategic managers with different names: the president of the company, Managing Director, Executive Director, Board of Directors, strategic manager, top management, etc. They use techniques and knowledge they have acquired through the formal system of business education, as well as through practice and experience gained in the management of business and other organizations. In the last decade analyses have shown that companies with strategy and educated strategic managers had better business results than those without them.

This general effort to point out that strategy is science denied in fact the opinion that strategy is dominated by skill. If you accept this point of view, strategists would be trained in a different way, i.e. by practicing, training, simulation and tests based on real situations.

\subsection{Arguments that support the claim that strategy is not science}

In the current theoretical and practical flood of management concepts, it is difficult to put strategy as a science into question, and every paper on this topic is indeed a risky undertaking. However, the strength of facts and reasoning by itself can lead into doubt and dilemma as to whether and to what extent strategy is science, just how much skill it contains, i.e. whether strategy is primarily art and only then science, which is a dilemma for Clausewitz, too.

The first argument that strategy is not science is that its laws are not based on scientific grounds, which are scientifically validated, as in other sciences. In strategy- 
creating effort strategic management does not dispose of enough scientifically verified information. Strategy is the result of strategic thinking, which may be more or less, or completely subjective, thus losing objectivity and scientific basis for making strategic decisions. It turns out that strategy is a mental process, partly based on individual perceptions.

Thus, strategy is accompanied by a high level of subjectivity in the interpretation of the same facts and the execution of final conclusions, or legality of the same, which is not the case with other, primarily the natural sciences. For example, in medical science strategic decisions that determine the life and death of patients are arrived at based on confirmed and scientifically proven facts, standards and procedures that do not leave room for different interpretations. The outcome of these and other decisions is predictable. If we apply the same methodology of treatment with the same drugs and therapeutic agents to patients with the same symptoms and diagnosis, it is very likely that we will get the same result. Any doctor must justify his every decision and base it on the experimentally confirmed facts and scientifically verified procedures and standards. Those are: laboratory analysis, X-rays, graphics, and estimation of the quantification. In the case of complex problems, they are obliged to convene a council, where, from the perspective of holistic concepts, they evaluate the outcomes of specific interventions and their effects on the whole organism (Walshe, \& Undall, 2001).

The situation is the same when it comes to technical science. If we are to make a project of a bridge of certain capacity, with a high level of accuracy we can calculate the necessary resources, such as compressive strength, section steel profiles and fittings, etc. Data and standards leave no room for different interpretations or different conclusions. If you fail to comply with these standards, the capacity of the bridge becomes problematic.

However, with strategy this is not the case. If we apply the same strategy to solve the same problems in the organizations of the same activities with the same organic composition of capital, the same number of employees and the same value of assets, we shall end up with different, and often completely opposite results. In one case, the same strategy can produce satisfactory, while in other cases negative effects, which brings into question its scientificity.

Also, experience shows that the strategies that had been proven successful in the past, in another time dimension may be unsuccessful, and may even produce damage to the company, which is rare in other sciences, primarily in natural sciences. This leads us to the conclusion that in strategy there is a problem of scientific value, and that it suffers from the problem of objectivity in drawing conclusions and laws.

Another argument that strategy is not science is the fact that there is no clear and scientifically verified methodology in its formulation and implementation, and there is no strategy for the development of strategy. The question is whether it is possible at all to establish it in the first place. Because of the above, every organization formulates its own strategy, which is the result of strategic management's skills to evaluate environmental factors and their own internal forces in order to respond to changes in the environment. Therefore, even though the facts are the same, the difference between strategy and strategic decisions may find itself in a wide range in the way of their formulation and implementation.

This argument is often disputed, and it is often emphasized that the main reason for the differences are the people in different organizations. It turns out that organizations with greater percentage of human labor, as is the case in the service sector, are more susceptible to variations in the final result. However, there are differences in the treatment of humans, too. If we know that there are no two same people on earth, and we know that every person is different from another, how is it possible that different people take same drugs with more 
or less same expected effects, whether by the outcome (positive or negative), and by the time necessary for drugs to produce results. It is obvious that medical science has managed, through scientific experiments, to arrive at scientific information that is universal and whose outcome is expected in each patient, just as it is expected by every medical professional.

A relatively strong argument that strategy is not science lies in the fact that Sun Tzu in his book 'The Complete Art of war' (approximately 509 BC) elaborates the art of war that comes down to the skills of issuing instructions, commands and explanations, and the practicing of small units through segmentation, articulation and maneuverability as the primary goals of military preparation. The key idea of this military leader was that we should not strive to defeat the enemy by engaging in armed conflict, but to prevail without battle as such, which is the area of diplomacy. (Sun $\mathrm{Cu}, 2005$, p.21-36).

In the past, as in modern times, a number of successful businessman had no knowledge of the strategy as a science, yet they managed to create and maintain their empires which last to this day. Their skills and ability to assess the current situation and use it appropriately is not a matter of science, but rather matter of skills. Finally, one of the most successful people in the last two decades had been Steve Jobs who had no formal education, who knew nothing about management and strategy, but still he managed to make his company competitive and in the industry considered to be highly volatile. The situation is similar with other big names in the world of business, in the world of manufacturing, hospitality, banking, etc.

The problem of strategy in strategic management increases if we bear in mind that Japanese companies do not have or are abandoning strategy as a basic tool for the realization of the set goals. Japanese management sticks to one and the same strategy, which is to produce the best quality products and services with the lowest possible cost price and selling price. In this context, there are different techniques and tactics, such as quality management, just-in-time, encouragement and use of innovation, creative imitation, etc. Abandonment or marginalization strategy is the first sign or symptom that it is not effective in creating greater business success.

If we are to conclude that strategy is not a science, the question arises to what extent the availability of databases and their use improves the quality of strategic decisions. The business literature is full of case studies and observations that the development of information technology has significantly improved the process of strategic decision-making, because the data can be obtained faster and better. However, studies on the example of 330 public north American companies showed that companies that use massive databases policy decisions have had a better business success by $5-6 \%$ compared to their competitors, as measured by the increase in value of the shares on the stock exchanges. This study showed that about $50 \%$ of strategic managers make decisions based on intuition and experience (McAfee, \& Brynjolfsson, 2009). The fact is that more information lead to better predictions, and this inevitably leads to better decisions. However, it is shown that the use of massive files, in the absence of scientific information, cannot significantly improve the business success of organizational systems, which imposes the primary need to establish a scientific basis for the formulation and implementation of strategy, and then to increase the use of the database.

From the above we might conclude that there is room to doubt the scientificity of strategy, because there is not enough evidence that its conclusions are based on objective, i.e. is scientific facts. Therefore, it is more realistic to view strategy as a science and art, leaving us with the question to what extent one or the other phenomena are present. One of the reasons for the above might be the fact that for decades the dominant concept was Porter's concept of formulation and implementation of strategies, never reviewed nor upgraded. 


\section{The necessity of introducing medicine into formulation and implementation of strategy}

Without going into further analysis of whether and to what extent strategy is a science, i.e. to what extent it contains skills, the fact remains that Porter's concept of strategy is no longer applicable, because it is based on mechanistic-deterministic basis, which does not correspond to turbulent times. This is a paradox indeed, especially since Sun Tzu believed that "the key element in fighting is spirit, or chi, which is the vital energy of life itself. It is evident, therefore, that as early as $500 \mathrm{BC}$ people were aware of psychology in which spirit was the basis of many aspects of Chinese thought, from metaphysics to medicine. It is not clear, however, how did spirit - governed by will and intent - disappear from warfare, and why is it so scarce in the works of classic management theorists and classic strategy.

Instead of the mechanistic-deterministic approach, it is necessary to perceive strategy from the standpoint of strategy biologistical-medical sciences, which is logical, because strategy is the result of thought process and mental energy that exists in man. Functioning of man, and especially the relationship between the brain and the executive body parts can analogously be applied to strategic management. Brain or top management has the ability to think and to make mental constructions, i.e. to make real alternatives and decisions. Body or those who implement decisions should put to practice what brain had envisioned. Therefore, man works as follows: (1) first ideas and strategies are formulated in the human brain, and (2) the execution of strategy through the body or organization. Body obediently carries out the decisions of the brain. Arms, legs, other parts of the body do not get to choose what they will do; the brain decides. Orders are a one way street and go from the brain to the executable parts of the body, as is the case with information ranging from the brain, i.e. from higher level of awareness towards parts with lower level of awareness.

Medical professionals, especially neurologists may not agree with such a simplified representation of the brain functioning. It turns out that from the standpoint of strategy and strategic management this metaphor is correct. It can be used to formulate strategice process, but also for its implementation, especially if one is familiar with the anatomy and physiology of the human activities as a conscious human being.

On the other hand, getting to know the source or root from which strategy arises is important, because he who does not know where he comes from cannot know where he is going to. It turns out that every effect must have a cause, and if we want to turn strategy into a scinece and an efficient concept, we must influence the cause, or the human mind that is able to produce mental constructions, make real alternatives and select the most advantageous variants of turning it into a decision.

\subsection{The source of strategy and strategic process}

Strategy is the result of a thought process and creativity of strategic management. It occurs in the human brain, which consists of the left and right hemispheres. Each of the two parts produces different strategies or different quality strategies (Radosavljević, 2004).

The left side of the brain is based on logic, analyticity, gradual development and respect for processes and procedures. It processes the information in a linear manner, from parts towards the whole, i.e. proceeds from the parts, assembles them into a logical entity and on that basis draws final conclusions. People who have a more developed left side of the brain prefer to make plans, priority lists, schedules and graphics representing 
the strategic process. In presenting their strategic thinking, the strategists of this sort use symbols, logical maps, symbols and formulas. Therefore, strategists with more developed left side of the brain present their ideas and strategic assessment in a clear, direct and understandable way for analysts, but also for those who are to implemente that strategy. They often use analogies trying to analytically and directly give instructions on how to reach the goal. Strategists who have a more developed left brain hemispheres implement strategies according to established policies and priorities, and when the strategic goal is achieved, they perform analysis of the strategic process in order to draw certain conclusions.

The right side of the brain has the capability of creativity, intuition, improvisation and the ability to immediately solve the problem. This side wants to see words, symbols and ideas in a wider context, and how they function in real life, or in practice and on the field. Persons and managers at the top of the hierarchical pyramid with the more developed right side of the brain find it difficult to provide the right words to explain their ideas, because ideas keep coming up, which is why there is often confusion. Therefore, general decisions are most often produced, and they are later implemented in details. In other words, the right side is capable of deductive reasoning, i.e. it starts from the whole to the parts where it first constructs a large strategic picture, which then presents the exact goal we must achieve. In this context, people with more developed right hemisphere have no clear priorities, they are not oriented deterministically, often tend to miss deadlines because they are willing to parallely perform multiple jobs. They do have a very strong sense of intuition, i.e. they are albe to sense a problem, and further they can also sense the right answer. However, they see neither analytical nor operational ways to solve the problems.

The above analysis indicates and proves that dominance of either left or right side of the brain determines the quality of strategy, as well as its creation and implementation. Strategists who have the right side of the brain more developed, as a rule, tend to better formulate strategy due the greater presence of creativity. They have more alternatives and the ability to choose the most suitable one and turn it into a strategic decision. Therefore, if we conclude that our problem with strategy is its formulation, clarity and ability to predict future events, it is necessary to strengthen the strategic management with experts who have the right side of the brain more developed, or we must attempt work to strengthen the right side of the brain.

The dominance of the left side of the brain determines that focus is more on the practical side of strategy and its implementation. Managers with this feature follow the processes, procedures and standards set out in the strategic decision and are suitable for the executive office or for operational and tactical management, through which the strategy is implemented. If we conclude that the strategy is well formulated and the problem is its implementation, strategic management, or administrative committees must strengthen the management team with professionals who have the left side of the brain as dominant.

However, recent studies in the United States have denied the above claims that dominance of either left or right side of the brain in strategic managers determines the quality of strategy, and generally determiines strategic management of organizational systems. It has been proven that the most successful strategic managers are those with balanced left and right sides of the brain. It is evident beyond doubt that managerial work is dynamic, complex and accompanied with a number of uncertainties. Therefore, when necessary, strategic managers must think logically and methodologically, but they also must be creative, intuitive and unencumbered with the rules and procedures laid down in the formulated strategy. 
Generally speaking, as stated above, the left and right sides of the brain process information in different ways; what the outcome will be and what kind of decision the brain will make depends on which side of the brain is dominant in every single individual. In any case, experience has shown and proven that the process of thinking, i.e. the process of stratetic thinking is more successful when both left and right sides of the brain participate. Accordingly, each person should strengthen and consciously promote one side of the brain that is less dominant, so that both sides are brought into balance, i.e. that we reduce differences between them.

The above findings are significant for the selection of people who are to be admitted to the management schools and trained to perform the most complicated tasks. In the eighties, the Harvard Business School in enrollment of prospective students demanded brain scan, to determine the dominance of the left or right side of the brain. If the side that created creativity dominated, it was felt that these individuals had greater potential for answering more complex questions in the world of business. However, if focus was on practicality or management executive jobs, students with a more developed left side of the brain wer admitted.

The introduction of medicine in strategy and strategic management has led to the discovery of a new quality of people involved in the strategic management and the formulation and implementation of strategy. In addition to the intellectual potential and talent, future strategists must constantly educate themselves and train to respond to new problems in the world of business and strategic management. Therefore, it is now impossible to be successful if we apply the concept of strategy suggested by Porter a few decades ago, in much the same way that current concepts will not be able to solve the problems of the future.

\subsection{The relationship between mental energy and strategy}

Any action or activity is conditioned on using some form of energy. This principle applies both to technology and man-made mechanisms, as well as to man. Therefore, man as a conscious and rational must in his activities use mental and physical energy. In other words, man must first conceive what to do and how to do that for which he needs mental energy. After that, man is to implement the management decision for which he must use physical energy, i.e. the power of his muscles, or of the power of man-made mechanisms. When using mental energy and creating thoughtful design, or concepts, one does not need to use physical energy, but when he does use the physical energy it is necessary to use mental energy and intelligence as its product.

Strategy is closely related to mental energy, which is logical because strategic process is the result of mentality, from the formulation to implementation of strategic ideas. Thus, mental energy is energy that is created in the human neocortex, and it is the result of the movement of neurons. It creates mental and strategic processes, and this in turn creates mental activity in receiving pulses from the environment and the establishment of functioning of self-organization, i.e. organizational systems in accordance with the conditions in the environment.

Mental energy is analogous to electricity. Just as electricity has positive and negative poles, mental energy too has its own emotional and motivational halves. If one pole is lacking there can be no electricity. In that same way, if either emotional or motivational energy is missing there can be no mental processes, and thus no mental activity. Accordingly, without mental energy there is no strategic process and strategy as a result of thoughtful design (Vučenović, 2013).

Emotional pole creates needs and wants in a man. Desire arises in the mind. If a man wants something, conscience shall tell that to the subconscious mind which will fulfill the request of consciousness, without any question whatsoever. Subconscious is 
the builder of the body and is able to heal, which is natural, because the law of life is the law of faith, and faith is thought that is born in mind. Every person and every organization has its own needs and this is the source of the foundation of all social organizations.

In the classic strategy, emotional intelligence is neglected or marginalized. It used to be believed, and is still so, that one should exclude emotions from business and in general from any form of work althogeter because they 'kill' success. This belief further produced the classic management claim that strategy should rely on material resources, and that man must perform according to the dictates and instructions of strategic management. Just how unacceptable this attitude is today is evident from the fact that today those organizations and individuals that take into account emotions that create desire and build them into their strategy are the successful ones. Without this element, it is difficult to be competitive, because every organization whose reliability is based upon man is unreliable.

It turns out that is the biggest problem, because objectively there is a large gap between wishes and possibilities. This law applies both to individuals and communities. In fact, in every new time dimension man displays not only new needs, but also expansion of existing needs, especially when it comes to quality of satisfying the needs. On the other hand there is the problem of limited resources, which in each new era keep getting carcer, and their availability becomes uncertain. In fact, strategy should answer the question as what is the most appropriate way to implement the strategic concept. Strategy should make it possible for us to achieve our goals and satisfy our needs with less effort and other expenses, i.e. to enable us to maximize our results while minimizing our economic sacrifices. Strategic management should, using strategy as a tool, develop needs and desires thereby enhancing the emotional pole. Through feedback, this emotional pole should then positively affect the creation of desire. This further means that strategy is not a goal, but an instrument for achieving the defined objectives.

Motivational pol produces will, i.e. wish and motivation to fulfill desire. If a man, or if any organization have the desire, but not the will to implement the strategy, the desire remains useless. That is why the classical strategy and theory of management kept searching for different ways to motivate employees and encourage them to meet the objectives. Sun Tzu saw rewards and punishments as the main levers of military victory. He favoured rewards and marginalized punishments, feeling that they can be applied only after the creation of an emotional basis. In other words, to quote Sun Tzu: 'If punishment is applied to the army before they become devoted to his commander, the army will not be submissive. If the army is not obedient, it is difficult to use it in combat. If punishment is not applied after the soldiers became devoted to his commander, then the soldiers are unusable (Sun Cu, 2006, p.40).

In this context Maslow's pyramid of motives is also based on the need; today it is the basis for the study of motivation, although it does not provide entirely universal application, especially when it comes to the order of satisfying the needs of higher rank. Bearing this in mind, the strategy should address both the emotional and motivational element, but also the necessity that strategic management must create needs, i.e. desires, and must motivate participants to implement the strategy.

\subsection{Integration of (will) desires, knowledge and opportunities - condition for strategic success}

What distinguishes successful and unsuccessful man, or a successful and unsuccessful organization? Why some can hardly provide their own survival, while others are successful even in times of crisis? Are there any differences between two successful men, or two successful organizations? The answers are complex, but they more or less boil 
down to the fact that successful emit positive energy creating their own model of the world, they are confident of success, and they integrate desire, knowledge and capabilities into the definition and implementation of goals. Richard Bandler and John Grinder, who created the technique of neuro-linguistic programming (NLP) dealt with this problem (Harvard Business Review 2011).

Any strategy must integrate its resources so that through to the synergistic effect it can achieve greater effect than if individual potentials acted separately. Therefore, we see that integration creates synergy, and synergy is free energy, which is obtained by the simultaneous action of force on an object, phenomenon, or process. It turns out that the special effects in any strategy can be realized by integrating desires, knowledge and opportunities.

It turns out that willpower can arouse desire in the mind of another person and lead to appropriate action, i.e. lead to complex effects on the minds of others, through the socalled induction of mental activity. The quality of the strategy depends on the mind, i.e. on thought structures as the driving force of everything that exists. In other words, every thought is a cause, and everything else is the consequence. The mind produces thought. If we are trying to change strategy, we must change the cause, i.e. we must change the way we use our own consciousness. Scientific and everyday practice show and prove that mind has nswers to all the questions, and it is actually an infinite intelligence. The greatest scientific discoveries in the future will entertain exploring in more detail the relationship between consciousness and subconsciousness, and their use in improving the health of people.

Desire and will are evident in every mental action. We should herewith also mention the possibility of satisfying the needs. It turns out that is conditioned on three elements that are interconnected as follows (Radosavljević, 2006b, p.11-19):

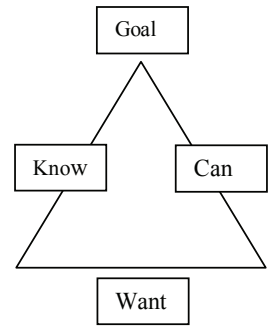

We clearly see that the basis of everything is will, i.e. or desire to achieve something. If we wish that something gets achieved, then there is no obstacle to prevent this from happening. All we have to do is want, and that is the biggest problem for which we develop special techniques to act on the people's consciousness in order to develop motives or stimulus that will trigger human energy for a certain action or lack of action. The techniques of neurolinguistic programming are able to increase will, i.e. desire. It turns out that everything man dreams can be achieved. In other words, desire is the starting point, but it remains nothing but an empty wish if there is no will to see it realized.

Given the above, the verb 'want' is on the base of the triangle, upon which the whole strategy is based, as well as general management processes in the organization. This verb is the assumption of mental activity, i.e. will needs to propel mental energy and create the effect. In the context of the strategy, it is quite possible that there might be high intensity of desire or need to formulate a strategy that will achieve competitive advantage, but if there is no will on the part of employees and other stakeholders to see 
it implemented, it remains but an idea. Practice in a large number of companies shows that they come up with strategies of excellent quality, but these are not implemented due to lack of will. This element in achieving the desire simply cannot be bought, it must be created within the organization.

Strategy always counts on reality, i.e. on the possibility of its implementation, in order to produce certain effects. Strategy should identify its own capabilities as well as environment conditions, and should use them to achieve competitive advantage. This is the reason why we undertake to evaluate conditions and market competition, our strengths and weaknesses, opportunities and chances - in order to create the most advantageous strategic concept based on these elements. If strategy is formulated as a simple wish list, and there is no possibility for it to be implemented, then it is utopia rather than a concept that deserves special attention. In that case it is even better to have no strategy, rather than to have unrealistic and impossible strategy.

The third element of making wishes come true is to know how to reach effect through strategy. Practice shows that we may not know how to achieve a certain thing, but if there is will or desire to achieve that, we shall find people who know how to do it, pay them and they will eliminate the problem. The same applies to the (im) possibility. Human brain has this ability to - through the process of thinking continuously about a problem create mental constructions in order to create the opportunity for the realization of an idea or strategy. This conclusion is logical, because mind has the answer to all the questions and problems of the cosmos, because every phenomenon has its cause, and its discovery was the result of a thought process, which manifests itself as a universal intelligence.

It is evident that compatibility between will, opportunities and knowledge is the prerequisite for achieving strategic success. The smaller the disproportion between these two phenomena, (i.e. the greater the coherence), the more efficient and effective man becomes. Therefore, one must first wish, and then want, i.e. have the will to implement that. When this harmony is established, brain has the ability to design a way for the realization of their ideas and strategies. The more you think how to achieve your desire, or goal, the more it will produce higher quality alternatives; further, the best alternative transforms itself into management decision, i.e. into strategic decision that will have a high quality application and implementation.

Regarding mental energy it is important to know that it is unlimited. In every human being there is enough mentality to live on it. Whether this energy will be launched and used depends on the person, i.e. whether he wants to put it to use providing his own survival and progress. The problem is that human mental energy is very little used, and it is estimated that this does not exceed $10 \%$ of its potential. One of the reasons for lack of success today and the emergence of modern crisis is that mental resources are insufficiently used through new strategic concepts and innovations in organizing and managing organizations. This conclusion is logical, because let us imagine that in an organization resources, i.e. potentials (raw materials, technology, employees) are used by $10 \%$, could that system survive in an increasingly competitive and uncertain market. Even minimal increase in the use of mental energy would lead to substantial progress both in the micro and macro levels, which boils down to the phrase that 'we need to work smarter, not work longer hours.'

\section{Holistic-systemic view of strategy}

Modern science emphasizes that no scientific law or scientific discovery can last forever, but that everything is subject to permanent reviewing and proving its authenticity in accordance with new scientific knowledge. This also applies to the 
strategic management and strategy. These phenomena too need to be reviewed in line with changes in the technological, organizational, social and political context. At its beginnings, scientific research was aimed at researching the rules and laws of functioning of natural self-organization, and the cosmos and its parts, and later directed its attention to other self-organization, and above all, man.

In the period from the fifteenth century, science had developed the classic Cartesian scientific method based on the principles of mechanicism and determinism. This scientific method of research has been to this day applied in the formulation and implementation of strategy. It turns out that in the eighties this concept was dominant with Porter when considering business and competitive strategy. As such, it has contributed significantly to progress in social development.

However, modern scientific discoveries show that the classic method in the formulation and implementation of strategy has become a limiting factor in scientific research. This is because the Cartesian method is able to provide only partial knowledge of natural laws. Most certainly, 'one can not deal with just one subsystem and expect to solve the systemic problem. Systemic problems require systemic solution's (Adizes, 2011, p.187). This method did not take into account the cause as the primary element in identifying and defining the manifested problems, processes and phenomena.

Now we are aware of the evident need to introduce into the scientific methodology the concept of integrity instead of the mechanistic concept of the whole. This is the need to introduce monitoring of all the elements of the strategic process from the perspective of the whole, or in their mutual relations and interactions. In other words, every part of the strategy affect other parts, as well as the very whole, and a whole must also be connected and interact with the environment in which the strategy works. Biologistical physics and medical science significantly contributed to this concept by introducing the principle of stochasticity, and the discovery of information as the third required component of the organization.

Observing strategy, we can say that it is a particularly organized structure of the whole, whose quality characteristics can not be inferred from the quality of the parts that make up this particular unit. For example, it is impossible to perform the analysis of the quality of the strategy of certain elements, such as situation assessment, strategy formulation, implementation, etc. Classic theory which is still dominant today insists on those concepts in the formulation and implementation of strategy. It turns out that each element of the strategy must be viewed in its entirety, i.e. within the relations among elements, as well as its relationship with the environment to which the organization belongs. This stems from the indisputable position which was once defined by Plato and Aristotle where the whole is always more than a simple sum of the quality of the parts of which it is composed. This is another alpha plus, i.e. Aristotle called those relations between the parts the very soul of the organization.

This theory has a number of practical implications. In this context, it should be borne in mind that it is wrong for strategic management to appoint teams, agencies and consultants to formulate a strategy and, then to name other teams that have the task to implement the strategy. Certainly, this conclusion is natural, because it is necessary that there is unified strategic thinking, and that the one who formulated the strategy has to work on its implementation. Let us imagine a situation in which in combat certain generals only define strategy, and the others are in charge of its implementation. In other words, some are to perform strategic assessment, and the others are to create strategy based on that. Or imagine that into war combat we introduce strategists who did not participate in strategy formulation. Let us imagine a situation in which the strategy was formulated outside the coach of a sports team, and the coach was left with implementing 
that strategy. This could produce negative effects in these cases, but the situation is the same in the sphere of business.

Hence, there is the practice of appointing strategic management for the duration of the strategy. With the change of strategic management it is difficult, if not impossible, for current strategy to survive, especially if it is a dynamic and changing industry. This does not mean that outside experts cannot be used in certain parts of the strategic process, but they should not dominate; they simply cannot produce a sound strategy based on strategic thinking of someone else who does is not familiar or not familiar enough with the given phenomenon, no matter how relative this phenomenon might be.

Practice shows that also in theoretical terms it is not correct too emphasize the formulation and implementation as two elements of the strategic process, because they are two sides of the same coin. If this is not the case, the professionals who formulate strategy will often ignore its application feeling that other teams shall deal with that problem, and those who implement the strategy have no idea about the whole strategic concept and the strategy as a whole.

On the other hand, it should be borne in mind that the strategy should be seen as an entity consisting of certain parts, such as: operational art, and tactics through which it is implemented. The quality of strategy is particularly evident in its implementation. High quality strategy is the one that has a satisfactory outcome for all stakeholders who are directly or indirectly realize their interests in the organization, or through the organization. A strategy that does not bring satisfactory effects cannot be viewed as successful and must be changed.

Further, strategy is part of a subsystem of policy from which it stems and through which it realizes the policy of shareholders and owners. If there is no policy, there is no strategy, which is natural, because if there is no whole, there can be no functioning parts. Policy, however, can function without strategy, and these phenomena should be viewed as between whole and parts. In other words, a whole can exist and survive without parts, but parts cannot exist without the whole. This rule derives from medical science. Indeed, man can survive and function without legs, arms, or other parts, but hands or feet cannot function without a body. Radosavljević, 2006a, p.236-244).

The previous statement is important for the strategy, as strategic management in reaching strategic decisions must take into account first of all the whole that is more important than parts. Accordingly, the strategist must often sacrifice the interests of the parts in order to - through these sacrifices - achieve a greater effect on the level of the whole. This rule too is the result of medical science, which was among the first to implement the principle of holism. Surgeons and teams of consultants often make decisions about the removal of certain parts of the body in order to save lives. Otherwise, there would be a threat to survival, as the first and primary goal of all living beings and organizations.

Application of holism and holistic concept of strategy and strategic management will become more and more important, because it increases the complexity and interdependence of the parts within the organizational systems, as well as between the organization and the environment in which they operate. It must be established attitude, it's all part of a whole and at the same time, some parts of the unit, which are interconnected and iterative relations.

Therefore, we can improve the quality of the strategy by improving the relationship between the parts of the strategy, particularly in terms of increased complexity and interdependence between the individual parts, as well as by improving relations between the parts and the whole, i.e. between whole and the environment in which it operates. At the same time, the interaction between the individual elements of the strategy produces a 
new energy, which is called synergy. This is possible in conditions where implementation strategies differ from strategic ideas and strategic decisions, and when we take corrective strategic decisions, which are simultaneously applied in practice. Synergy is the free energy, i.e. energy that is obtained without additional financial investment. Therefore, if there is a dynamic synchronization and communication between the parts, then they produce a new quality that can not be inferred from the quality of the parts.

\section{Problems in formulation and implementation of strategies}

It has already been noted that in modern conditions classic strategies are generally applied, i.e. strategies that are taught in high schools and business as a result of the classic theorists strategy. These strategies mainly refer to normal times, i.e. to times that were less turbulent, and in which there was relative stability in the business. Since normal operating conditions are becoming rare, it is necessary to conceive the so-called crisis strategies, i.e. adaptive and flexible strategies seldom referred to in classic strategy.

It should be borne in mind that the modern world has changed, and there are less and less traditional organizations. Instead of permanent jobs today there are occasional and temporary jobs, performed from a distance, thanks to the use of information technology. Employing people 'at a distance has brought about the question whether offices are necessary, and it has provided more satisfaction for the employees since they can choose their working hours.

This is the biggest change of them all since the traditional managers simpoly cannot grasp that employees perform tasks without being seen by the management. According to estimates, 'perhaps one-quarter of all jobs in the United States can be done remotely' A survey of 2,000 USA companies was conductd in 2011; one-quarter of them plans in the future to introduce or increase the number of 'remote' employees. These studies have shown that the number of these jobs increases four times faster than the increase in total employment over the past ten years (Lund, Manyika, \& Ramaswamy, 2012). It is clear, therefore, that the above has considerably changed our understanding of strategy, but it also changes the way we create and implement strategy. All the changes mentioned above demand that first we change the strategic management and adopt the new reality: this is, without doubt, the hardest thing to do.

Strategy as a phenomenon is understood in many different ways, and it is also differently diversified. In many cases, it answers the question of 'what', i.e. what the goals of the organization are, which is unacceptable. Goal or goals are determined by the policy, i.e. by the board of directors, or by the owner himself. Strategy, on the other hand should answer the question of how to achieve these goals. From this it follows that trategy is a part of policy, i.e. a subsystem of policy. If there is no policy, there can be no strategy, which is natural, because these two things should be considered as the relation between whole and parts, i.e.whole can exist without parts, but parts cannot exist without the whole.

The above fact is indeed important, as we often formulate either branch or corporate strategies, without making national strategy first. This is a result of fashionable trends and does not help successful goal setting. For example, it is not possible to formulate the strategy for the development of tourism, agriculture, or other activity, if there is no national strategy. This for the simple reason that national strategy should define at the macro level the general way to achieve national goals and interests, and the national 
strategy as a whole should arise special (branch) concepts that will determine the most efficient and effective way of implementing the objectives in this area.

\subsection{Differences between strategies}

Instead of classic and universal strategies modern business is dominated by adaptive and strategies that shape the environment. This is in line with the level of technological, organizational, managerial, and cultural-social and other changes that have happened and that are happening in modern conditions. Given the diversity of organizational systems, the general characteristic is that today there are no uniform, but different and unique strategies. It turns out that there are no two strategies that are the same, because there are no two same organizations or same business ambience in which they operate or work. To what extent this axiom is neglected is evident in the fact that at the global level for certain areas the so-called global strategies are created. For example, at their meeting in May 2007 the Ministers of Education of the Bologna countries adopted an international strategy that emphasized the need for ENRA to be more open and attractive to students from other parts of the world, as well as to strengthen higher education collaboration and political dialoque with non-European. (Prosvetni pregled, 2013, p.3). The situation is similar in other areas, too.

It is clear that objectives and means are mixed up here, that it is impossible to formulate a strategy without taking into consideration differences, because each strategy is produces in the first place in order to respond to new challenges in specific temporal, spatial, cultural, political, social, religious, and other customary conditions. It turns out that these conditions vary in different countries of Europe and there is a big difference between European and non-European countries. Therefore, this is a typical example of the classic, i.e. uniform strategy, which may not give a satisfactory result.

Therefore, it is absurd to either copy of take a strategy from another organization or system. It turns out that each strategy corresponds to a particular organization, and situation. In other words, within the same branch one strategy is formulated for large and another one for small and medium enterprises. Moreover, strategies change depending on the lifetime of the organization. In the phase of creation or birth, we formulate adaptive strategies, because this is the most sensitive stage in the development of an organization. In the maturity stage, when the environment is less adaptable, classic concept of strategy should be applied. This is completely completely opposite compared to the Porter's concept and concepts of other classic theorists. (Reeves M Love, \& Tillmanns, (2012, p.2).

In adaptive strategy, strategic planning which is based on the concept of the classic strategy loses its importance that had lasted for many decades. Instead of designing universal strategies which are based on stable elements and whose quality is evaluated through the length of their survival, the modern concept is based on flexibility and strategic plans have been replaced with maintaining permanent 'daily battles'. Accordingly Hispanic Zara has the adaptive strategy based on a flexible supply chain. This strategy allows for production of new models of clothes in an average of 2-3 weeks, while the industry average is 4 to 6 month. Shortening the life cycle of the fashion industry is a significant asset to this company. Thanks to the above, Zara has managed to take over a significant market share from other companies, such as Marks and Spencer and others. To this we should add one more alpha plus, which is that the relations between the participants in the supply chain are partnership relations, i.e. completely different from the classic strategy in which each member follows solely his own interests, without taking into account the other participants.

Another, perhaps the most important quality of modern strategy is the attempt to shape and change the environment. In a classic strategy, SWOT analysis is a commonly 
used tool for the design of strategies, i.e. concept of assessing their own strengths and weaknesses and comparing them with the opportunities and threats that come from the environment, as well as demographic, socio-cultural, technological, economic and other types of segmentation. (Dess G., Lumpkin T. \& Eisner A. 2008, p.44).

In modern terms, strategy is focused on the potential outside the organization, taking into account the ecosystem, customers and suppliers, creating new standards of technological processes and generally favorable environment for the development of organization and strategy. Instead of the classic strategies approach which insisted that the organization responds to changes in the environment, through the strategy of "shaping" the organization seeks to shape the business environment in its favor. For this the techniques of marketing, lobbying and partnerships in various forms are being used. Thanks to these techniques, Facebook had in a very short time overtaken My Space and became one of the most important social networks for communication between different entities in the supply chain, but also between organizations and environments.

The shaping strategy is particularly applicable in varying industries, such as digital marketing, IT industry, fashion and other areas. Contrary to the above, the classic strategies have greater success in traditional industries, such as automotive, oil, mining and other less volatile sectors. The classic strategy is also applicable in industries where there is monopoly, or domination of individual national economies globally. However, they too are changing and adapting to new trends.

The introduction of foresight in the shaping strategy results in a higher level of quality because here we attempt to shape the future, or to find out what the future will actually look like in the coming period. Practice shows that certain companies have the ability to shape and predict the future, but are not ready for a radical strategy. The example of the Chinese Tata company confirms the above conclusion. The company has already constructed the ultra-nano car and promoted the following strategy: 'Create and they will come.' The fact is that in strategy waiting will never bring a satisfactory effect, including the above mentioned waiting, but we must seek things and, according to the old Christian custom, must take into account the strategy: 'Seek and you shall find.'

\subsection{The problem of strategy implementation}

The quality of a strategy is determined by its implementation. Strategy can be well formulated, but still with a problem in its implementation, namely that the assumptions on which the strategy was formulated are not real and deviate from the situation in the organization, the environment, especially in the market. Therefore, Einstein was probably right when he once said that we should spend the most of our time on defining a certain problem, and especially on the cause of a particular problem, phenomenon or process, and then we should try to resolve it.

Analyses show that strategies often fail due to lack of coordination in the organization. Disagreements are inevitable, when employees often attribute their failures to other departments, mostly to finance and marketing, and other functional departments that have their own procedures and principles of functioning. The problem with the strategy can be rectified through team defining of rules and deals that resemble contracts. (Sull, \& Eisenhardt,. 2012, p.4).

Analyses show that strategic management often attempts to define strategy, as well as its application, without having previously defined problems that the strategy needs to address. In just this kind of situation, strategists often solve the wrong problem the right way. For example, Kodak's leadership used to be inconsistent, because any change in management brought change in strategy. Although Kodak started with photographs in 
1880 , he was too slow to change his strategy and the photographic industry was taken by the Fujifilm, which won market. Because of this Kodak was losing tempo and dynamics. It turned out that the management of Kodak suffered from a mentality of perfect products, rather than think of new approaches. In other words, Kodak was trying to improve as much as possible, the wrong product. This shows that strategies are mortal because they are always exposed to the immortal fight between competitors. He who survives is the winner, only to be faced with danger at his very next step.

In the management practice there often occurs concern about the length of the preparation and scanning of the environment, and testing its own potential in the company. It turns out that there can be complaints by the board about certain managers that they tend to spend too much time on the diagnosis of the condition. In extreme conditions there can even be certain penalties. This approach is likely to further waste time, energy and money, leading the company into failure.

The problem of strategy as a concept is in the creation of special teams to formulate and other teams to implement the strategy. Creation of strategy is often entrusted to special organizations, consultants, agencies and other external entities, and implementation is left to other teams or managers. This is not the strategy of a given company, but someone else's strategy. In a broader context this is not even a strategy, but advice of consultants that usually fail. This is clearly a mistake, because the one who formulates strategy neglects its application, and one that applies has no view of the whole strategic concept. This is a consequence of too great insistence by theorists of strategy, i.e. by Porter himself that strategic process must consist of formulation and implementation of strategy.

Formulation and implementation of strategy are two sides of the same coin. One without the other does not make sense. Ignoring the above, in the words of Shakespeare, would be like having a theatre play with no Romeo, or Romeo with no play. Therefore, efforts should to keep formulation and implementation of strategies within the scope of strategic management, where one can still use external services. In other words, strategy must be comprehensive, and its theoretical division into formulation and implementation must not divide them, but bring them together. This is particularly evident in the theoretical aspect of strategy and strategic processes.

Strategy is formulated at the top of the hierarchical pyramid, and executed at all levels, through operations, and tactics. It is always related to the whole. Quality strategy should be simple. In other words, each strategy is more effective if employees use simple guidelines in making and implementing strategic decisions. To achieve the above, it is necessary that all those involved in implementation are also involved in creation of strategy. It turns out that strategy is too serious a thing to be left only to strategic management. There are too many people who love strategy, but too few of those who are willing to deal with its implementation, especially when certain difficult circumstances occur. Let us remember S. Jobs who was obsessed with creating elegant computers that are simple to use. He found that computers were difficult to use, especially for those who are not specialists, and the main cause was that there were too many engineers in the software industry. (Gelernter, 2011. p.1).

In formulating and implementing strategy one should take into account the cultural and sociological dimension of a particular company or organization. In classic, i.e. Porter's strategy it used to be ignored, or not given adequate attention. The classic strategy is more acceptable in cultures that are traditional and slow to change, and that reward efficiency and penalize flexibility. Strategies in these cultures survive for prolonged periods, there is no willingness to experiment and learn. It turns out that without the process of learning there can be no development strategy, nor the willingness 
to correct the same when circumstances change. In contrast to these, there are cultures that are favorable for the development of adaptive strategies, ready for rapid change, or that do not provide a greater resistance to change.

\section{Resume}

The analysis has showed that the classic concept of strategy, created in the eighties, is not able to provide satisfactory business success of organizational systems. The reason for the above is to be found in the classic postulates on which organizations were, such as hierarchical supremacy and subordination, determinism and giving excessive importance of material resources on one side and neglecting man as the basic resource of each organization. This reasoning provided satisfactory results with the overall effort to create a strategy that will provide more stability and development of the organization. Thanks to the above, a number of successful organizations had survived and realized the defined objectives.

Radical changes that have occurred in the last decade, and especially the changes in the organizational, technical, technological, economic and other aspects of the organization make it necessary to introduce a new, more flexible, and in particular adaptive strategy concepts, which will be based on science, and above all on biology and medicine. Most certainly, through application of these sciences it is possible to design and build organizations that would, in analogous manner, function on the basis of self-organization, as the most advanced mode of organization. It is evident that these concepts are better and are able to respond to all the increasingly complex and uncertain challenges that stand before the strategic management and organizations in general.

With the introduction of science in the process of formulating and implementing strategy, strategic management becomes an objective phenomenon that eliminates doubts and dilemmas whether strategy is a science, as well as numerous controversies that arise in strategic management. All this creates the conditions for strategic decisions in business organizations to be arrived at by using metaphors from factual medicine, i.e. that decisions are made on the basis of documentation, where the outcomes of those decisions woudl be certain. Through the use of analogies from the natural order, strategic management must scientifically document certain decision. Until then, there remain some serious doubts about the strategy as a science, because the same strategies produce different results, as well as different strategies can produce the same effects. In the end, we must remember the old wisdom by Naguib Mahfouz: 'You can tell whether a man is clever by his answers. You can tell whether a man is wise by his question.'

\section{References}

Adizes, I. (2011). Insights on Policy, Adizes Institute Publications.

Bartol, K.athryn M. \& Martin, David C.(1994). Management, (Mcgraw-Hill Series in Management), Mcgraw-Hill College, New York.

Sun $\mathrm{Cu}$ (2005). Umece ratovanja, Alnari, Beograd.

Dess, G., Lumpkin, T., \& Eisner, A. (2008). Strategic Management, Mcgraw-Hill International Edition.

Gelernter D. (2011). Seer of the mirror world, Harvard Business Review, from the Novembar Issue. 
Lund, S., Manyika, J. and Ramaswamy, S. (2012). Preparing for a new era of knowledge work, McKinsey Quarterly, November.

McAfee A., \& Brynjolfsson E. (2009). Big Date-Menagement Revolution, Enerprice, 2.

Millson M., \& Wilemon D. (2007). The strategy of managing innovation and tehnology, Prentice Hall, New Jersey.

Prosvetni pregled, (2013). Ka globalizaciji visokog obrazovnja, Beograd, 5 Dec 2013, pp 3.

Radosavljević, Ž.(2004). Menadžment u medicini i medicina u menadžmentu, Stilos, Novi Sad.

Radosavljević, Ž. (2006a). Menadžment u modernom biznisu, FORKUP, Novi Sad.

Radosavljević, Ž.(2006b). Trgovinski menadžment, FORKUP, Novi Sad.

Reeves, M., Love, C., \& Tillmanns, P. (2012). Your strategy Needs a Strategy, Harvard Business Review, from the September Issue.

Results or excuses? Taking responsibility for what you really want, Harvard Business Review (2011).

Sull, D., \& Eisenhardt, K. M. (2012). Simple rules for a Complex World, HVR From the septembar Issue.

Vučenović, V.(2013). Self-organization, manuscript, Decembar.

Walshe, K. and Undall, T.: Evidence-based Management: From Theory to Pracitce in Health Care, Univesrity of Bermingham, and University of California at Berkley“, 2001. 